\title{
Membrane proteomics of cervical cancer cell lines reveal insights on the process of cervical carcinogenesis
}

\author{
KALLIOPI I. PAPPA ${ }^{1,2}$, POLYXENI CHRISTOU ${ }^{3,4}$, AMARILDO XHOLI ${ }^{3}$, GEORGE MERMELEKAS ${ }^{3}$, \\ GEORGIA KONTOSTATHI ${ }^{3,4}$, VASILIKI LYGIROU ${ }^{3,4}$, MANOUSOS MAKRIDAKIS ${ }^{3}$, \\ JEROME ZOIDAKIS $^{3}$ and NICHOLAS P. ANAGNOU ${ }^{1,4}$
}

\begin{abstract}
${ }^{1}$ Cell and Gene Therapy Laboratory, Centre of Basic Research II, Biomedical Research Foundation of the Academy of Athens, 11527 Athens; ${ }^{2}$ First Department of Obstetrics and Gynecology, University of Athens School of Medicine, Alexandra Hospital, 11528 Athens; ${ }^{3}$ Biotechnology Division, Centre of Basic Research, Biomedical Research Foundation of the Academy of Athens; ${ }^{4}$ Laboratory of Biology, University of Athens School of Medicine, 11527 Athens, Greece
\end{abstract}

Received March 22, 2018; Accepted May 4, 2018

DOI: $10.3892 /$ ijo.2018.4518

\begin{abstract}
The available therapeutic approaches for cervical cancer can seriously affect the fertility potential of patient; thus, there is a pressing requirement for less toxic and targeted therapies. The membrane proteome is a potential source of therapeutic targets; however, despite the significance of membrane proteins in cancer, proteomic analysis has been a challenging task due to their unique biochemical properties. The aim of the present study was to develop an efficient membrane protein enrichment protocol, and to the best of our knowledge, to compare for the first time the expression pattern of membrane proteins of one normal cell line, HCK1T, and three cervical cancer cell lines, C33A, a human papilloma virus (HPV)-negative cell line, and two HPV-positive cell lines, SiHa (HPV16 ${ }^{+}$) and HeLa (HPV18 ${ }^{+}$. The study aimed to identify the proteins that are involved in cervical carcinogenesis and may constitute novel drug targets. Membrane protein isolation, liquid chromatography coupled with tandem mass spectrometry proteomics and bioinformatics analysis were performed in the membrane fraction of the informative cervical cell lines following a novel enrichment protocol. The percentages of membrane and transmembrane proteins in the enrichment protocol were higher compared with those of the corresponding data derived from total cell extract analysis. Differentially expressed proteins were detected by the comparison of the cervical cancer cell lines with the normal cell line. These proteins constitute molecular features of cancer pathology and participate in
\end{abstract}

Correspondence to: Dr Kalliopi I. Pappa, First Department of Obstetrics and Gynecology, University of Athens School of Medicine, Alexandra Hospital, 80 Vassilissis Sofias Avenue, 11528 Athens, Greece

E-mail: kalliopi.pappa20@gmail.com

Key words: cervical cancer, membrane proteins, proteomics, liquid chromatography coupled with tandem mass spectrometry, cervical cell lines biological pathways relevant to malignancy, including 'HIPPO signaling', 'PI3K/Akt signaling', 'cell cycle: G2/M DNA damage checkpoint regulation' and 'EIF2 signaling'. These unique membrane protein identifications offer insights on a previously inaccessible region of the cervical cancer proteome, and may represent putative diagnostic and prognostic markers, and eventually therapeutic targets.

\section{Introduction}

Cervical cancer is the fourth most common malignancy in women worldwide, caused by high-risk human papilloma virus (HPV) strains, mainly HPV16 and HPV18 (1-4), and if not treated promptly, could eventually lead to the development of malignancy. Cervical cancer incidence and mortality are declining in developing countries, mainly due to the introduction of effective screening tests $(5,6)$. The treatment of cervical cancer relies on surgical interventions combined with radiotherapy methods that may cause fertility impairment $(7,8)$. Despite significant efforts in the last 20 years, novel therapeutic approaches have not been introduced in clinical practice $(9,10)$. The reason for this delay is the paucity of comprehensive studies on the actual molecular determinants of cervical malignancy that could open the way for the identification of novel therapeutic targets. Such an approach can actually be effective, as is illustrated by the recent paradigm of bladder cancer. The characterization of the molecular landscape of bladder cancer led to the introduction of the first targeted therapy for the disease, namely employing antibodies that inactivate programmed death receptor 1 /programmed death receptor ligand 1 (11). This paradigm indicates that membrane proteins are excellent therapeutic targets, and that an efficient approach to characterize them in depth is actually offered by proteomic methods $(12,13)$. Membrane proteins are involved in important processes, including signal transduction, cell communication and molecule transport. Additionally, their systematic study could eventually lead to the identification of biomarkers for prognostic or diagnostic purposes.

The systematic analysis of the proteomic studies of cervical cancer cell lines by our group, involving their secretome and 
the total cell extract (14-16), offered several exciting insights on the biological processes relevant to cervical cancer pathology, including cytoskeletal remodeling and redox signaling. However, the membrane proteome has not been investigated thus far due to its particular biochemical properties, such as hydrophobicity (12). Thus, the aim of the present study was to develop an efficient and reproducible membrane protein enrichment protocol, and to the best our knowledge, to compare for the first time the expression of membrane proteins of four informative cervical cell lines, one derived from normal cervical keratinocytes (HCK1T) and three cancerous types, C33A (HPV), SiHa (HPV16 ${ }^{+}$) and HeLa (HPV18+).

\section{Materials and methods}

Cell culture. The cancer cell lines SiHa $\left(\mathrm{HPV}_{16}{ }^{+}\right)$, HeLa $\left(\mathrm{HPV}^{+} 8^{+}\right.$) and C33A (HPV), commercially available from the American Type Culture Collection (Manassas, VA, USA), were cultured as previously described (17). HCK1T cells were kindly provided by Dr Tohru Kiyono (Division of Carcinogenesis and Cancer Prevention, National Cancer Center Research Institute, Tokyo, Japan) and were cultured as previously described (18). A cell pellet of $\sim 10^{7}$ cells $/ 75-\mathrm{cm}^{2}$ flask was stored at $-20^{\circ} \mathrm{C}$ until use. Four biological replicates were used for each cell line.

Total protein isolation. The collection of the total cell extract was performed as previously described (14).

Membrane protein isolation. Initially, the cell pellet was resolubilized in $1 \mathrm{ml}$ of solution 1 [25 mM Tris- $\mathrm{HCl}(\mathrm{pH} 7.5)$ (Bio-Rad Laboratories, Inc., Hercules, CA, USA), 45\% sucrose (Fluka, Munich, Germany), $1 \mathrm{mM}$ EDTA (Gibco; Thermo Fisher Scientific, Inc., Waltham, MA, USA), $150 \mathrm{mM} \mathrm{NaCl}$ (AppliChem GmbH, Darmstadt, Germany) and $10 \mathrm{mM} \mathrm{MgCl}$ (Sigma-Aldrich; Merck KGaA, Darmstadt, Germany), with protease inhibitors (Roche Diagnostics, Basel, Switzerland) at $3.6 \% \mathrm{v} / \mathrm{v}$ final concentration], incubated for $20 \mathrm{~min}$ on ice, and homogenized with Dounce homogenizer 10-20 times. Sonication was used to achieve cell lysis, followed by centrifugation for $10 \mathrm{~min}$ at $2,000 \mathrm{x} \mathrm{g}$ at $4^{\circ} \mathrm{C}$, with aspiration of the supernatant and removal of the pellet. Solution $2[25 \mathrm{mM}$ Tris- $\mathrm{HCl}(\mathrm{pH} 7.5), 150 \mathrm{mM} \mathrm{NaCl}$ and $10 \mathrm{mM} \mathrm{MgCl}{ }_{2}$ ] was added to the supernatant to a final volume of $2 \mathrm{ml}$. Furthermore, ultra-centrifugation at $100,000 \mathrm{xg}$ was performed for $1 \mathrm{~h}$ at $4^{\circ} \mathrm{C}$ to collect the pellet containing the membranes. The pellet was solubilized in $2 \mathrm{ml}$ of solution 2. Ultra-centrifugation was performed at $100,000 \mathrm{xg}$ for $1 \mathrm{~h}$ at $4^{\circ} \mathrm{C}$. The resulting pellet was solubilized in $432 \mu \mathrm{l}$ of solution 3 [25 mM Tris- $\mathrm{HCl}(\mathrm{pH} 7.5)$, $150 \mathrm{mM} \mathrm{NaCl}$ and $3.6 \% \mathrm{v} / \mathrm{v}$ protease inhibitors]. This step was followed by the addition of SDS (Bio-Rad Laboratories, Inc.) to a final concentration of $2 \% \mathrm{w} / \mathrm{v}$, and the solution was incubated for $30 \mathrm{~min}$ at room temperature. Ultracentrifugation was performed at $100,000 \times \mathrm{g}$ for $1 \mathrm{~h}$ at room temperature. The supernatant was transferred to centrifugal filter units with a 30-kDa cutoff (Merck KGaA), which contained $3.5 \mathrm{ml}$ of solution 3 , followed by further centrifugation at $2,500 \mathrm{x}$ at $12^{\circ} \mathrm{C}$, until a final volume of $100 \mu \mathrm{l}$ was obtained. Total protein quantitation was performed using the Pierce BCA protein assay (Thermo Fisher Scientific, Inc.).
Sample preparation for liquid chromatography coupled with tandem mass spectrometry (LC-MS/MS). From each cell membrane protein solution, $10 \mu \mathrm{g}$ was analyzed by $12 \%$ SDS-PAGE, and stained with Coomassie Colloidal Blue (Fluka) overnight. Bands were excised from the gels and cut in small pieces $(1-2 \mathrm{~mm})$. Gel pieces were destained in $40 \%$ acetonitrile (Fisher Chemical, Loughbrough, UK) and $50 \mathrm{mM}$ $\mathrm{NH}_{4} \mathrm{HCO}_{3}$, reduced in $10 \mathrm{mM}$ dithioerythritol and $100 \mathrm{mM}$ $\mathrm{NH}_{4} \mathrm{HCO}_{3}$ (all from Sigma-Aldrich; Merck KGaA), and alkylated in $50 \mathrm{mM}$ iodoacetamide (Applichem $\mathrm{GmbH}$ ) and $100 \mathrm{mM} \mathrm{NH}{ }_{4} \mathrm{HCO}_{3}$ (Sigma-Aldrich; Merck KGaA). Samples were dried using the Savant Speedvac ${ }^{\mathrm{TM}}$ concentrator (Thermo Fisher Scientific, Inc.) and trypsinized overnight with $600 \mathrm{ng}$ trypsin (Roche Diagnostics) in $10 \mathrm{mM} \mathrm{NH} \mathrm{NCO}_{3}$. Peptide extraction was performed by two washes of the trypsinized gel pieces with $50 \mathrm{mM} \mathrm{NH}_{4} \mathrm{HCO}_{3}$, followed by two washes with 50\% acetonitrile and 5\% formic acid (Sigma-Aldrich; Merck KGaA) for $15 \mathrm{~min}$ at room temperature, with agitation. Extracted peptides were dried using the Savant Speedvac concentrator and analyzed by LC-MS/MS. The same protocol was also followed for the total cell extract.

$L C-M S / M S$. Dried peptides were solubilized in $100 \mu 1$ ultrapure water and separated on an UltiMate 3000 Nano HPLC Dionex Ultimate ${ }^{\circledR} 3000$ RSLS system (Dionex ${ }^{\mathrm{TM}}$, Camberly, UK). Initially, $5 \mu$ from each sample was loaded on a Dionex $0.1 \times 20 \mathrm{~mm}, 5-\mu \mathrm{m} \mathrm{C} 18$ nanotrap column, at a flow rate of $5 \mu \mathrm{l} / \mathrm{min}$ in $98 \%$ mobile phase $\mathrm{A}(0.1 \%$ formic acid $)$ and $2 \%$ mobile phase $\mathrm{B}$ (100\% acetonitrile and $0.1 \%$ formic acid). In the next step, the sample was eluted into an Acclaim PepMap C18 nanocolumn, $75 \mu \mathrm{m} \times 50 \mathrm{~cm}$ (Dionex), at a flow rate of $0.3 \mu \mathrm{l} / \mathrm{min}$. The trap and the nanoflow column were maintained at $35^{\circ} \mathrm{C}$. The samples were eluted with a gradient of solvent B, starting at $1 \%$ B for $5 \mathrm{~min}$, and rising to $5 \% \mathrm{~B}$ at $10 \mathrm{~min}, 25 \% \mathrm{~B}$ at $180 \mathrm{~min}$ and $65 \% \mathrm{~B}$ at $240 \mathrm{~min}$. The column was then washed and re-equilibrated prior to injection of the next sample. The eluant was ionized using a Proxeon Nano Spray Electron Spray Ionization source (nebulizer pressure, $100 \mathrm{psi}$ ), operating in positive ion mode into an Orbitrap Elite FTMS (ThermoFinnigan MAT GmbH, Bremen, Germany). Ionization voltage was at $2.6 \mathrm{kV}$ and the capillary temperature was at $200^{\circ} \mathrm{C}$. The mass spectrometer was operated in MS/MS mode scanning from 380 to 2,000 atomic mass units. The resolution of ions in MS1 was 60,000, and 7,500 for higherenergy C-trap dissociation (HCD) in MS2. The top 20 multiply charged ions were selected from each scan for MS/MS analysis using HCD at 35\% collision energy. Data analysis was performed with Proteome Discoverer 1.4 software package (Thermo Fisher Scientific, Inc.), using the SEQUEST search engine (19) and the UniProt Universal Protein Knowledgebase (http://www.uniprot. org/). The search was performed using carbamidomethylation of cysteine as static modifications and oxidation of methionine as dynamic modifications. Two missed cleavage sites, a precursor mass tolerance of $10 \mathrm{ppm}$ and a fragment mass tolerance of $0.05 \mathrm{Da}$ were allowed. SEQUEST results were filtered for false-positive identifications. The procedure of LC-MS/MS was followed for the analysis of the membrane fraction and the total cell extract.

Classification of membrane proteins and validation of the enrichment membrane protocol. Subsequent to selecting the 
Table I. Protein identifications in four biological replicates and identifications present in $75 \%$ of biological replicates.

\begin{tabular}{lcc}
\hline $\begin{array}{l}\text { Cell } \\
\text { line }\end{array}$ & $\begin{array}{c}\text { Total identifications } \\
\text { obtained from four } \\
\text { biological replicates }\end{array}$ & $\begin{array}{c}\text { Identifications present } \\
\text { in 75\% of biological } \\
\text { replicates, } \mathrm{n}(\%)\end{array}$ \\
\hline C33A & 3,213 & $1,961(61)$ \\
HeLa & 2,975 & $1,827(61)$ \\
SiHa & 2,477 & $1,522(62)$ \\
HCK1T & 2,132 & $854(40)$ \\
\hline
\end{tabular}

reliable protein identifications of membrane fractions, which were present in $75 \%$ of cancer biological replicates, they were categorized based on their subcellular location. This was achieved by employing the UniProt database (http://www.uniprot.org/). To confirm the successful enrichment of the isolation protocol, the number and the net percentages of membrane and transmembrane proteins were defined and compared with the membrane fraction and the total cell extract.

Quantification and statistical analysis. Quantification analysis was performed at the peptide level. The intensity for each protein in each biological replicate was normalized, i.e., quotient of intensity for the particular protein to the sum of all intensities of all proteins of the specific biological sample, multiplied by $10^{6}$. The mean normalized intensity for each protein was then determined for all biological replicates. The aforementioned procedure was repeated for all cell lines.

Only proteins present in $75 \%$ of the samples in at least one group were further processed for quantification and statistical analysis (Mann-Whitney). Differentially expressed proteins selected for further analysis were considered as those with a fold-change value of either of $>2$ (upregulated in a cancer cell line compared with the normal HCK1T cell line) or $<0.5$ (downregulated in a cancer cell line compared with the normal HCK1T cell line), and with a P-value of $<0.05$. This comparison resulted in three lists of differentially expressed proteins (C33A vs. HCK1T, HeLa vs. HCK1T and SiHa vs. HCK1T).

Ingenuity ${ }^{\circledR}$ Pathway Analysis (IPA).The identified differentially expressed proteins were subjected to IPA ${ }^{\circledR}$ analysis (Qiagen, Inc., Valencia, CA, USA; www.qiagen.com/ingenuity). Entry names of differentially expressed proteins were converted to gene names following their entry in the Retrieve/ID mapping of the UniProt database (http://www.uniprot.org/). The processed gene names were imported into IPA to map the canonical pathways and generate biological networks. Data were submitted as fold-change values, i.e., ratios, calculated against the control group (HCK1T). Hypothetical networks were built among the experimental proteins and the IPA database proteins. Only statistically significant $(\mathrm{P} \leq 0.05$, Fisher's Exact Test performed by the Ingenuity ${ }^{\circledR}$ Pathway Analysis platform) canonical pathways were selected. Canonical pathways were classified according to the P-value and the expression ratio in the cervical cancer cell line compared with that in the HCK1T cell line. The ratio of the canonical pathways was calculated based on the number of molecules from the input dataset divided by the total number of molecules in the pathway that was predicted by IPA. Molecules participating in the important canonical pathways according to IPA analysis were listed by their gene names.

Protein-protein interaction (PPI) network. A PPI network of the 174 common differentially expressed proteins among the three cancer cell lines and the normal HCK1T cell line was constructed using the Search Tool for the Retrieval of Interacting Genes/Proteins (STRING) v10.5 database (http://string-db.org/). The confidence score was set to $>0.4$.

\section{Results}

Overview. The overview of the present study approach is presented in Fig. 1. The aim was to develop a novel reproducible protocol for the isolation and enrichment of membrane proteins, and their subsequent characterization by mass spectrometry and bioinformatics analysis.

Reproducibility. The membrane protein enrichment protocol exhibited satisfactory reproducibility, since $40-62 \%$ of the total identifications were present in at least $75 \%$ of the biological replicates of the four cell lines studied. The numbers of reliable protein identifications are shown in Table I.

Comparison of membrane fraction vs. total cell extract. The percentage of membrane proteins identified in the four cell lines ranged from 38 to $44 \%$ and the percentage of transmembrane proteins from 20 to $24 \%$ (Table II). These percentages were higher compared with the corresponding data obtained from total cell extract analysis following the same workflow (Fig. 2; and Pappa et al, unpublished data). The mean enrichment ratio of membrane proteins identified by this approach compared with that of the total cell extracts was 1.5 , and 2.1 for the transmembrane proteins. In addition, the number of unique transmembrane proteins identified by the present protocol was higher compared with the transmembrane protein identifications obtained from the total cell extract, as shown in Table II.

Analysis of protein differential expression in the SiHa, HeLa, C33A and HCKIT membrane fractions. Comparison of the expression levels of the proteins in the membrane fraction of the four cell lines was conducted using a total of four samples per category, corresponding to different biological replicates. Each cancer cell line was compared with the normal HCK1T cell line. Differentially expressed and statistically significant proteins (fold-change $>2$ or $<0.5 ; \mathrm{P}<0.05$, Mann-Whitney) were identified by this analysis. Upregulated proteins in cancer were considered as those proteins either with a fold-change value $>2$ or being unique in a cancer cell line. Downregulated proteins in cancer were considered those with a fold-change value $<0.5$ or being unique in the normal HCK1T cell line. The following results were obtained from the comparisons of the HCK1T control cell line with the three cervical cancer cell lines. A total of 102 differentially expressed proteins (54 downregulated and 48 upregulated in $\mathrm{SiHa}$ ) were detected from the $\mathrm{SiHa}$ vs. HCK1T comparison, whereas 264 were identified only in $\mathrm{SiHa}$ (upregulated in $\mathrm{SiHa}$ ) and 61 only in HCK1T (downregulated in SiHa). Furthermore, 162 differentially expressed proteins 


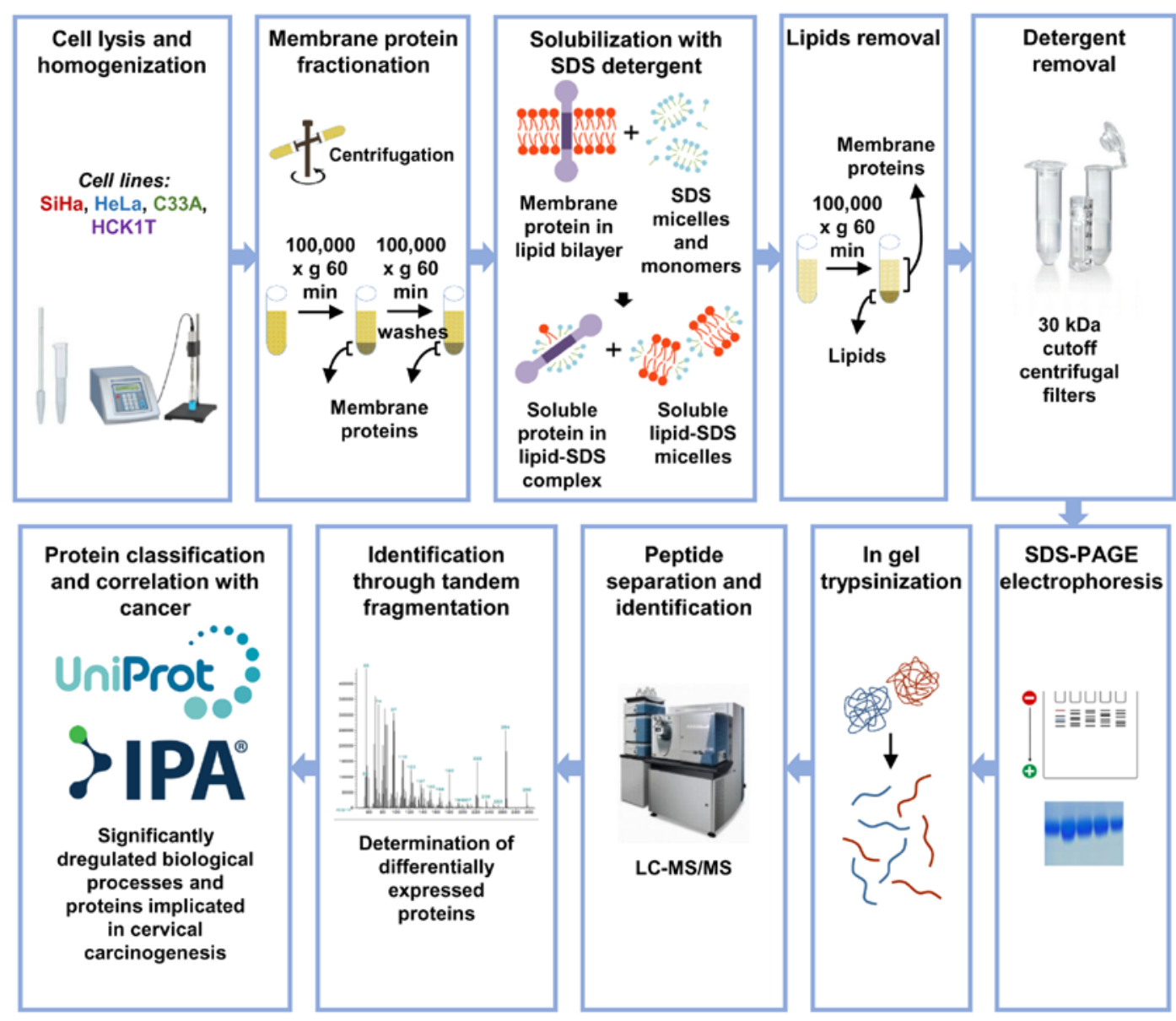

Figure 1. Outline of the experimental approach involving the individual steps of the novel protocol for membrane proteomics. Membrane protein isolation, following the novel protocol, LC-MS/MS proteomics and bioinformatics analysis were performed to reveal differentially expressed proteins between normal and cancerous cervical cell lines. LC-MS/MS, liquid chromatography coupled to tandem mass spectrometry; IPA, Ingenuity ${ }^{\circledR}$ Pathway Analysis.

Table II. Reliable protein identifications present in $75 \%$ of biological replicates of the four cell lines.

\begin{tabular}{|c|c|c|c|c|c|c|}
\hline $\begin{array}{l}\text { Cellular } \\
\text { fraction }\end{array}$ & $\begin{array}{c}\text { All protein } \\
\text { identifications, } \\
\mathrm{n}\end{array}$ & $\begin{array}{c}\text { Unique } \\
\text { identifications, } \\
\mathrm{n}\end{array}$ & $\begin{array}{c}\text { Membrane } \\
\text { protein } \\
\text { identifications, } \\
\mathrm{n}(\%)\end{array}$ & $\begin{array}{c}\text { Unique } \\
\text { membrane } \\
\text { protein } \\
\text { identifications, } \mathrm{n}\end{array}$ & $\begin{array}{c}\text { Transmembrane } \\
\text { protein } \\
\text { identifications, } \\
\mathrm{n}(\%)\end{array}$ & $\begin{array}{c}\text { Unique } \\
\text { transmembrane } \\
\text { protein } \\
\text { identifications, } \mathrm{n}\end{array}$ \\
\hline $\begin{array}{l}\text { C33A total } \\
\text { cell extract }\end{array}$ & 2183 & 891 & $544(25)$ & 163 & $186(9)$ & 52 \\
\hline $\begin{array}{l}\mathrm{C} 33 \mathrm{~A} \text { membrane } \\
\text { fraction }\end{array}$ & 1961 & 669 & 746 (38) & 367 & $398(20)$ & 263 \\
\hline $\begin{array}{l}\text { HeLa total } \\
\text { cell extract }\end{array}$ & 1912 & 664 & $552(29)$ & 95 & $202(11)$ & 20 \\
\hline $\begin{array}{l}\text { HeLa membrane } \\
\text { fraction }\end{array}$ & 1827 & 579 & 794 (44) & 337 & $444(24)$ & 262 \\
\hline $\begin{array}{l}\text { SiHa total } \\
\text { cell extract }\end{array}$ & 1961 & 826 & $563(29)$ & 170 & $199(10)$ & 32 \\
\hline $\begin{array}{l}\text { SiHa membrane } \\
\text { fraction }\end{array}$ & 1522 & 388 & $607(40)$ & 214 & $319(21)$ & 152 \\
\hline $\begin{array}{l}\text { HCK1T total } \\
\text { cell extract }\end{array}$ & 1712 & 1005 & $514(30)$ & 248 & $200(12)$ & 73 \\
\hline $\begin{array}{l}\text { HCK1T membrane } \\
\text { fraction }\end{array}$ & 854 & 147 & $361(42)$ & 95 & $200(23)$ & 73 \\
\hline
\end{tabular}




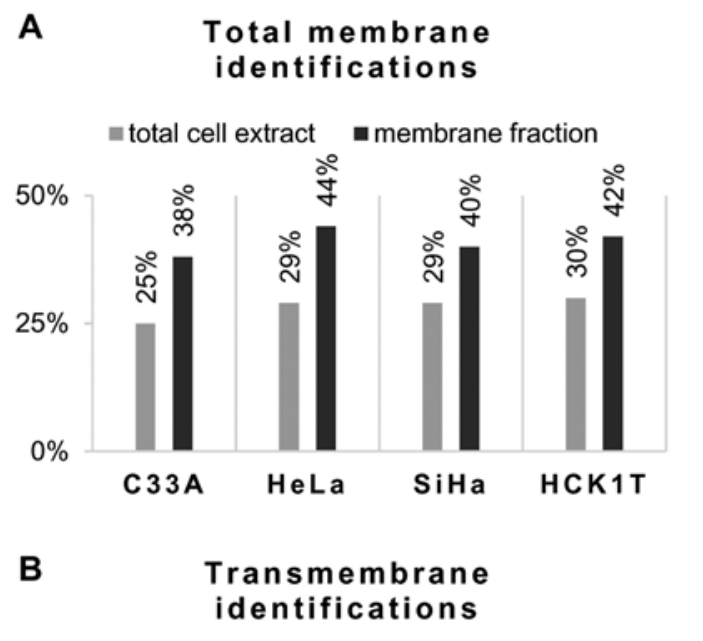

= total cell extract amembrane fraction

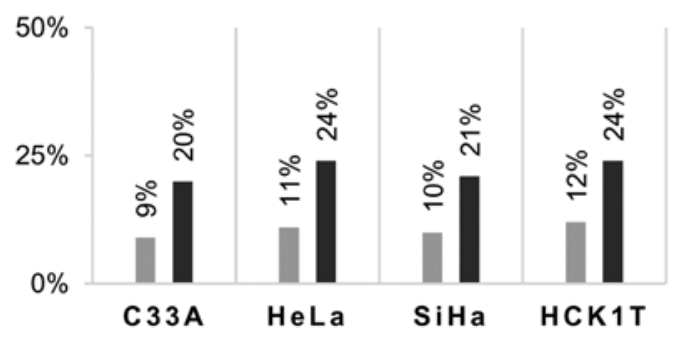

\section{Unique transmembrane identifications}

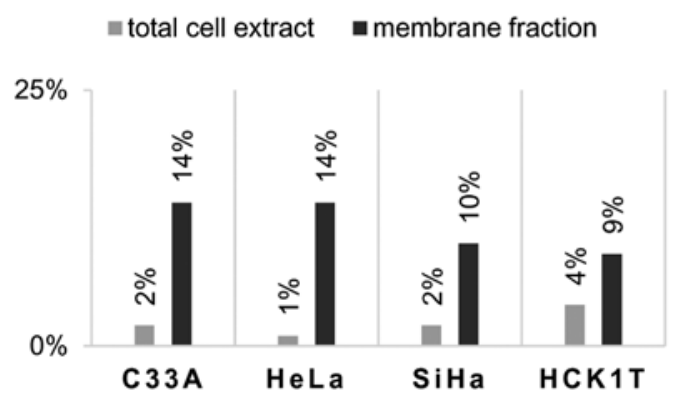

Figure 2. Comparison of percentages for the identified proteins between the membrane fraction and the total cell extract. (A) Total membrane protein identifications. (B) Transmembrane protein identifications. (C) Unique transmembrane protein identifications.

(59 downregulated and 103 upregulated in HeLa) were detected from the HeLa vs. HCK1T comparison, whereas 430 were identified only in HeLa (upregulated in HeLa) and 43 only in HCK1T (downregulated in HeLa). Finally, 169 differentially expressed proteins (90 upregulated and 79 downregulated in C33A) were detected from the C33A vs. HCK1T comparison, whereas 600 were identified only in C33A (upregulated in C33A) and 67 only in HCK1T (downregulated in C33A). The overlap between the upregulated proteins among the three cancer cell lines compared with the normal HCK1T cell line is presented by a Venn diagram in Fig. 3A. There were 131 common upregulated identifications that correspond to $42 \%$ of proteins in the $\mathrm{SiHa}$ vs. HCK1T comparison, $25 \%$ of proteins in the HeLa vs. HCK1T comparison and $19 \%$ of proteins in the C33A vs. HCK1T comparison (Fig. 3A). Additionally, there were unique differentially expressed proteins identified in all
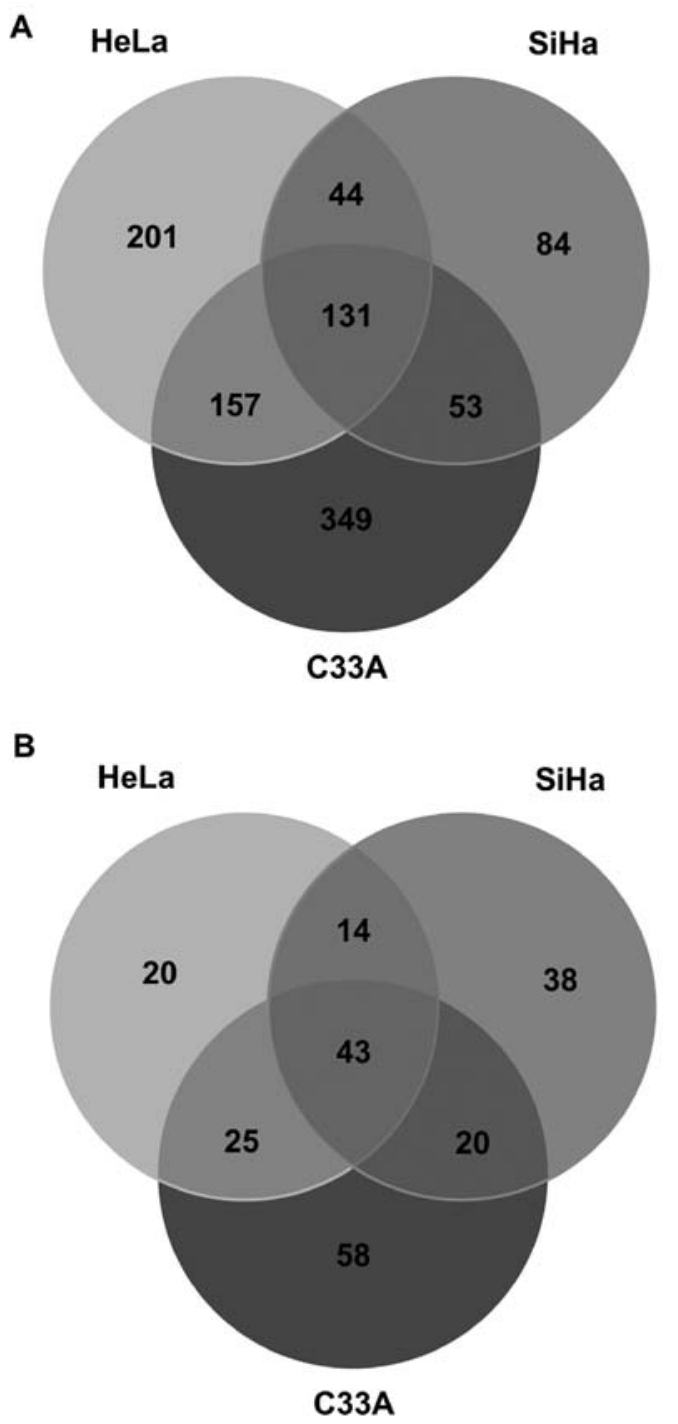

Figure 3. Overlap of differentially expressed proteins in the three cervical cancer cell lines compared with that in the normal HCK1T cell line. (A) Venn diagram for the upregulated proteins in cervical cancer cell lines compared with those in the normal HCK1T cell line. (B) Venn diagram for the downregulated proteins in cervical cancer cell lines compared with those in the normal HCK1T cell line.

comparisons (84 in SiHa vs. HCK1T, 201 in HeLa vs. HCK1T and 349 in $\mathrm{C} 33 \mathrm{~A}$ vs. HCK1T) corresponding to $27 \%$ in $\mathrm{SiHa}$ vs. HCK1T, $38 \%$ in HeLa vs. HCK1T and $51 \%$ in C33A vs. HCK1T. Furthermore, the overlap between the downregulated proteins among the three cancer cell lines compared with the normal HCK1T cell line is presented by a Venn diagram in Fig. 3B. There were 43 common identifications that correspond to $37 \%$ of proteins in the SiHa vs. HCK1T comparison, $42 \%$ of proteins in the HeLa vs. HCK1T comparison and $30 \%$ of proteins in the C33A vs. HCK1T comparison. Also, there were unique differentially expressed proteins identified in all comparisons (38 in SiHa vs. HCK1T, 20 in HeLa vs. HCK1T and 58 in C33A vs. HCK1T) corresponding to $33 \%$ in SiHa vs. HCK1T, $20 \%$ in HeLa vs. HCK1T and $40 \%$ in $\mathrm{C} 33 \mathrm{~A}$ vs. HCK1T.

The most prominent differentially expressed proteins (TMX2, FAM120A, CLPTM1, CKAP5 and NCSTN) that followed the same pattern of expression in all cancer cell lines 
Table III. Prominent membrane proteins involved in cancer pathology.

\begin{tabular}{|c|c|c|c|c|}
\hline $\begin{array}{l}\text { Gene } \\
\text { name }\end{array}$ & $\begin{array}{l}\text { Protein } \\
\text { name }\end{array}$ & $\begin{array}{l}\text { Regulation in cancer } \\
\text { (C33A, cell lines HeLa } \\
\text { and SiHa) vs. HCK1T }\end{array}$ & $\begin{array}{l}\text { Molecular } \\
\text { function }\end{array}$ & $\begin{array}{l}\text { Studies performed } \\
\text { in other types } \\
\text { of cancer (Ref.) }\end{array}$ \\
\hline TMX2 & $\begin{array}{l}\text { Thioredoxin-related } \\
\text { transmembrane protein } 2\end{array}$ & Upregulated & Cell redox homeostasis & $\begin{array}{l}\text { Upregulated in } \\
\text { breast cancer (20) }\end{array}$ \\
\hline FAM120A & $\begin{array}{l}\text { Constitutive coactivator of } \\
\text { PPAR- } \gamma \text {-like protein } 1\end{array}$ & Upregulated & $\begin{array}{l}\text { Oxidative stress-induced } \\
\text { survival signaling }\end{array}$ & $\begin{array}{l}\text { Upregulated in gastric } \\
\text { cancer }(21,22)\end{array}$ \\
\hline CLPTM1 & $\begin{array}{l}\text { Cleft lip and palate } \\
\text { transmembrane protein } 1\end{array}$ & Upregulated & $\begin{array}{l}\text { May play a role in } \\
\text { T-cell development }\end{array}$ & $\begin{array}{l}\text { Upregulated in colon } \\
\text { cancer (23) }\end{array}$ \\
\hline CKAP5 & $\begin{array}{l}\text { Cytoskeleton-associated } \\
\text { protein } 5\end{array}$ & Upregulated & $\begin{array}{l}\text { Cadherin binding, microtubule } \\
\text { plus-end binding }\end{array}$ & $\begin{array}{l}\text { Upregulated mRNA levels } \\
\text { in cervical cancer ( } 24)\end{array}$ \\
\hline NCSTN & Nicastrin & Upregulated & $\begin{array}{l}\text { Membrane protease cleaving } \\
\text { Notch receptors }\end{array}$ & $\begin{array}{l}\text { Upregulated in non-small } \\
\text { cell lung cancer }(25,26)\end{array}$ \\
\hline
\end{tabular}

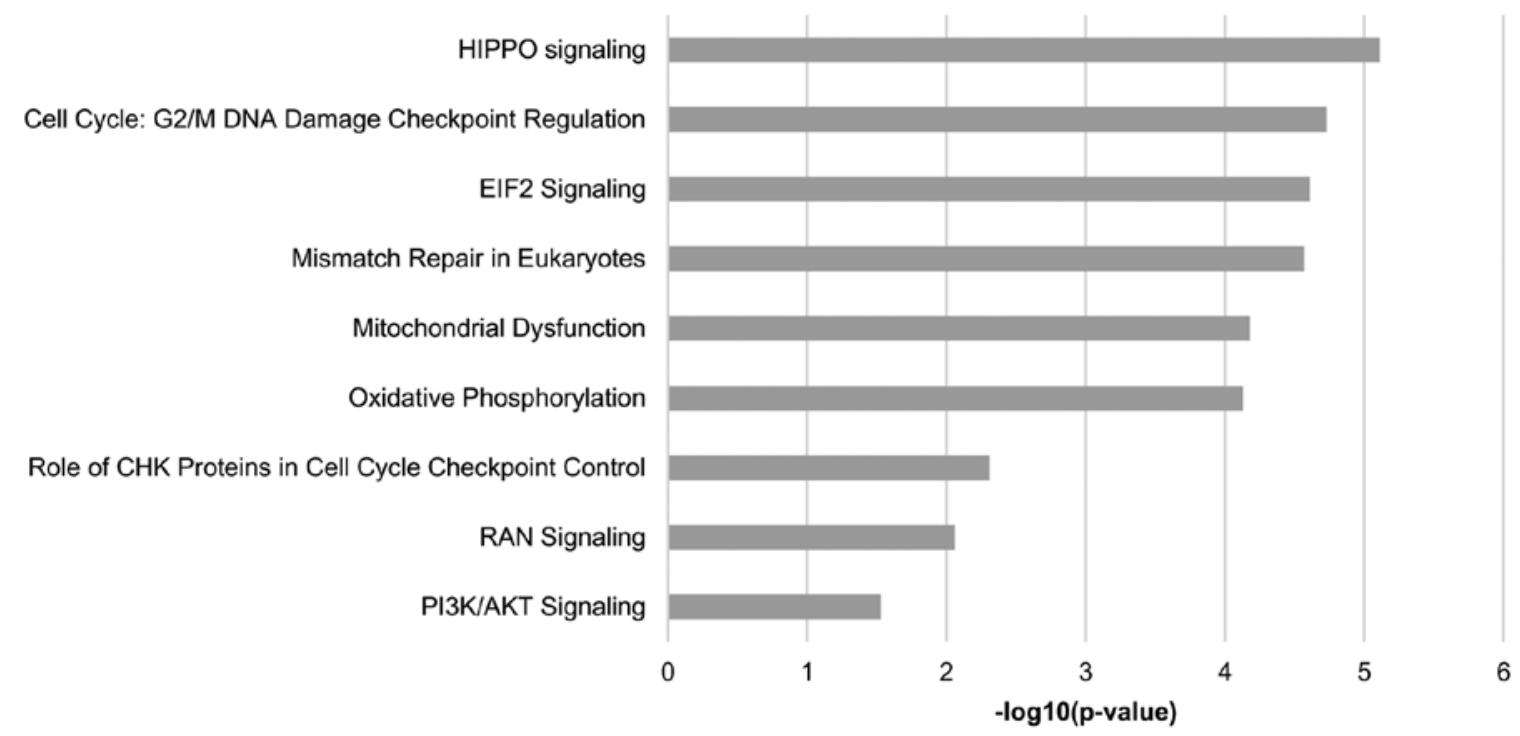

Figure 4. Ingenuity ${ }^{\circledR}$ Pathway Analysis results. Common pathways affected in the three cervical cancer cell lines in comparison with those in the normal HCK1T cell line.

are presented in Table III, along with information on their molecular function. Moreover, for these specific proteins, a literature search was performed on previous relevant studies describing their role in cancer biology (20-26), which was incorporated in Table III.

IPA and PPI network. To further characterize the biological functions and pathways relevant to the differentially expressed proteins, IPA software was employed. A total of nine pathways were found to be common among the three cancer cell lines compared with those in HCK1T cells, and are presented in Fig. 4. Among the common predicted pathways are 'HIPPO signaling', 'RAN signaling', 'PI3K/AKT signaling', 'cell cycle: G2/M DNA damage checkpoint regulation' and 'EIF2 signaling'. Furthermore, there were unique predicted pathways in all comparisons. Specifically, 19 pathways were predicted in SiHa vs. HCK1T (Table IV), 4 pathways in HeLa vs. HCK1T (Table V) and 33 pathways in C33A vs. HCK1T (Table VI). Transmembrane proteins are indicated in the tables.

Moreover, using the STRING database, a PPI network of the 174 common differentially expressed proteins among the three cancer cell lines and the normal HCK1T cell line was created. The network is presented in Fig. 5 and illustrates that 142 out of the 174 proteins have at least one functional connection.

\section{Discussion}

In the present study, an efficient and reproducible enrichment protocol for membrane proteins was developed, resulting in the identification of a significant number of unique membrane proteins relevant to cervical cancer. Moreover, the number of unique transmembrane proteins identified in the membrane fractions was higher compared with the total cell extracts. These unique transmembrane protein identifications offer 
Table IV. Canonical pathways and involved molecules in the SiHa cell line, as predicted by IPA ${ }^{\mathrm{a}}$.

\begin{tabular}{|c|c|c|c|}
\hline Ingenuity canonical pathways & P-value & Ratio & Molecules \\
\hline \multicolumn{4}{|l|}{$\begin{array}{l}\text { Common predicted pathways } \\
\text { in } \mathrm{SiHa}, \mathrm{HeLa} \text { and } \mathrm{C} 33 \mathrm{~A}\end{array}$} \\
\hline HIPPO signaling & $2.69 \times 10^{-5}$ & $1.30 \times 10^{-1}$ & $\begin{array}{l}\text { PPP1CC, YWHAQ, YWHAG, PPP1CA, SKP1, } \\
\text { PPP2R1A, YWHAZ, YWHAH, YWHAB }\end{array}$ \\
\hline $\begin{array}{l}\text { Cell cycle: G2/M DNA damage } \\
\text { checkpoint regulation }\end{array}$ & $4.27 \times 10^{-6}$ & $1.90 \times 10^{-1}$ & $\begin{array}{l}\text { TOP2A, YWHAQ, YWHAG, SKP1, YWHAZ, } \\
\text { YWHAH, YWHAB, TOP2B }\end{array}$ \\
\hline Mismatch repair in eukaryotes & $2.69 \times 10^{-5}$ & $4.55 \times 10^{-1}$ & PCNA, RFC2, RFC1 ${ }^{\mathrm{b}}, \mathrm{RPA} 1, \mathrm{RFC} 5$ \\
\hline Mitochondrial dysfunction & $6.61 \times 10^{-5}$ & $1.19 \times 10^{-1}$ & $\begin{array}{l}\text { FIS1 }^{\mathrm{b}}, \text { NDUFA } 5, \text { NDUFB9, SDHB, COX6B1, } \\
\text { ATP5H, PRDX5, ATP5A1, NDUFB6 }{ }^{\mathrm{b}}, \mathrm{NCSTN}^{\mathrm{b}}, \\
\text { COX7A2L }, \text { CYB5A }^{\mathrm{b}}, \text { ATP5F1, NDUFB }{ }^{\mathrm{b}}, \mathrm{MAOA}^{\mathrm{b}}\end{array}$ \\
\hline Oxidative phosphorylation & $7.41 \times 10^{-5}$ & $1.51 \times 10^{-1}$ & $\begin{array}{l}\text { NDUFA5, COX6B1, NDUFB9, SDHB, ATP5H, ATP5A1, } \\
\text { NDUFB6 }^{\text {b }} \text {, COX7A2L, CYB5A }{ }^{\mathrm{b}}, \text { ATP5F1, NDUFB3 }{ }^{\mathrm{b}}\end{array}$ \\
\hline PI3K/AKT signaling & $4.17 \times 10^{-4}$ & $9.18 \times 10^{-2}$ & $\begin{array}{l}\text { YWHAQ, YWHAG, CTNNB1, HSP90B 1, PPP2R1A, } \\
\text { YWHAZ, YWHAH, YWHAB, GYS2 }\end{array}$ \\
\hline $\begin{array}{l}\text { Role of CHK proteins in cell } \\
\text { cycle checkpoint control }\end{array}$ & $4.90 \times 10^{-3}$ & $1.40 \times 10^{-1}$ & PCNA, PPP2R1A, RFC2, RFC1 ${ }^{\mathrm{b}}, \mathrm{RPA} 1, \mathrm{RFC} 5$ \\
\hline EIF2 signaling & $1.82 \times 10^{-2}$ & $5.56 \times 10^{-2}$ & $\begin{array}{l}\text { RPS27L, PPP1CC, EIF3G, RPLP2, PPP1CA, } \\
\text { RPS7, RPS8, RPS14 }\end{array}$ \\
\hline RAN signaling & $3.00 \times 10^{-2}$ & $1.67 \times 10^{-1}$ & RANGAP1, KPNA2 \\
\hline \multicolumn{4}{|l|}{ Unique predicted pathways in $\mathrm{SiHa}$} \\
\hline Dopamine receptor signaling & $1.15 \times 10^{-2}$ & $8.47 \times 10^{-2}$ & PPP1CC, PPP1CA, PPP2R1A, SPR, MAOA ${ }^{b}$ \\
\hline Granzyme B signaling & $9.12 \times 10^{-4}$ & $3.33 \times 10^{-1}$ & BID, NUMA1 \\
\hline Cysteine biosynthesis III mammalia & $1.45 \times 10^{-3}$ & $1.11 \times 10^{-1}$ & AHCYL1, AHCYL2, AHCY \\
\hline ERK5 signaling & $1.74 \times 10^{-3}$ & $2.73 \times 10^{-1}$ & $\begin{array}{l}\text { YWHAQ, EGFR }{ }^{\text {b }}, \text { YWHAG, YWHAZ, } \\
\text { YWHAH, YWHAB }\end{array}$ \\
\hline $\begin{array}{l}\text { Methionine degradation I } \\
\text { to homocysteine }\end{array}$ & $2.29 \times 10^{-3}$ & $1.02 \times 10^{-1}$ & AHCYL1, AHCYL2, AHCY \\
\hline L-cysteine degradation III & $2.63 \times 10^{-3}$ & $1.19 \times 10^{-1}$ & GOT1 \\
\hline Interferon signaling & $2.82 \times 10^{-3}$ & $6.54 \times 10^{-2}$ & IFITM2 $^{\mathrm{b}}$, ISG15, IFITM3 ${ }^{\mathrm{b}}$ \\
\hline Aspartate biosynthesis & $4.79 \times 10^{-3}$ & $7.02 \times 10^{-2}$ & GOT1 \\
\hline Glutamate degradation II & $5.01 \times 10^{-3}$ & $7.69 \times 10^{-2}$ & GOT1 \\
\hline Unfolded protein response & $5.37 \times 10^{-3}$ & $1.88 \times 10^{-1}$ & HSPA9, DNAJC3, HSP90B1, HSPA5, ERO1B \\
\hline ERK/MAPK signaling & $2.09 \times 10^{-2}$ & $2.01 \times 10^{-1}$ & $\begin{array}{l}\text { HSPB1, PPP1CC, YWHAQ, STAT3, YWHAG, PPP1CA, } \\
\text { PPP2R1A, YWHAZ, YWHAH, YWHAB }\end{array}$ \\
\hline Myc-mediated apoptosis signaling & $2.29 \times 10^{-2}$ & $1.10 \times 10^{-1}$ & YWHAQ, YWHAG, YWHAZ, BID, YWHAH, YWHAB \\
\hline $\begin{array}{l}\text { Aldosterone signaling } \\
\text { in epithelial cells }\end{array}$ & $2.29 \times 10^{-2}$ & $5.03 \times 10^{-2}$ & 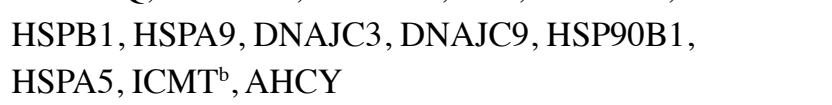 \\
\hline Protein ubiquitination pathway & $2.34 \times 10^{-2}$ & $1.11 \times 10^{-1}$ & $\begin{array}{l}\text { HSPB1, PSMD4, HSPA9, DNAJC3, DNAJC9, } \\
\text { HSP90B1, HSPA5, SKP1, B2M }\end{array}$ \\
\hline $\begin{array}{l}\text { Phenylalanine degradation IV } \\
\text { mammalian, via side chain }\end{array}$ & $2.51 \times 10^{-2}$ & $1.82 \times 10^{-1}$ & GOT1, MAOA $^{\mathrm{b}}$ \\
\hline Methylglyoxal degradation III & $2.69 \times 10^{-2}$ & $6.06 \times 10^{-2}$ & AKR1C3, AKR1B1 \\
\hline Endoplasmic reticulum stress pathway & $3.47 \times 10^{-2}$ & $1.54 \times 10^{-1}$ & DNAJC3, HSP90B1, HSPA5 \\
\hline IGF-1 signaling & $4.57 \times 10^{-2}$ & $5.04 \times 10^{-1}$ & $\begin{array}{l}\text { YWHAQ, STAT3, YWHAG, CSNK2A2, } \\
\text { YWHAZ, YWHAH, YWHAB }\end{array}$ \\
\hline 14-3-3-mediated signaling & $4.57 \times 10^{-2}$ & $5.10 \times 10^{-1}$ & VIM, YWHAQ, YWHAG, YWHAZ, YWHAH, YWHAB \\
\hline
\end{tabular}

${ }^{a}$ Molecules participating in the important canonical pathways according to IPA analysis are listed by their gene names; ${ }^{\mathrm{b}}$ Transmembrane proteins. IPA, Ingenuity ${ }^{\circledR}$ Pathway Analysis. 

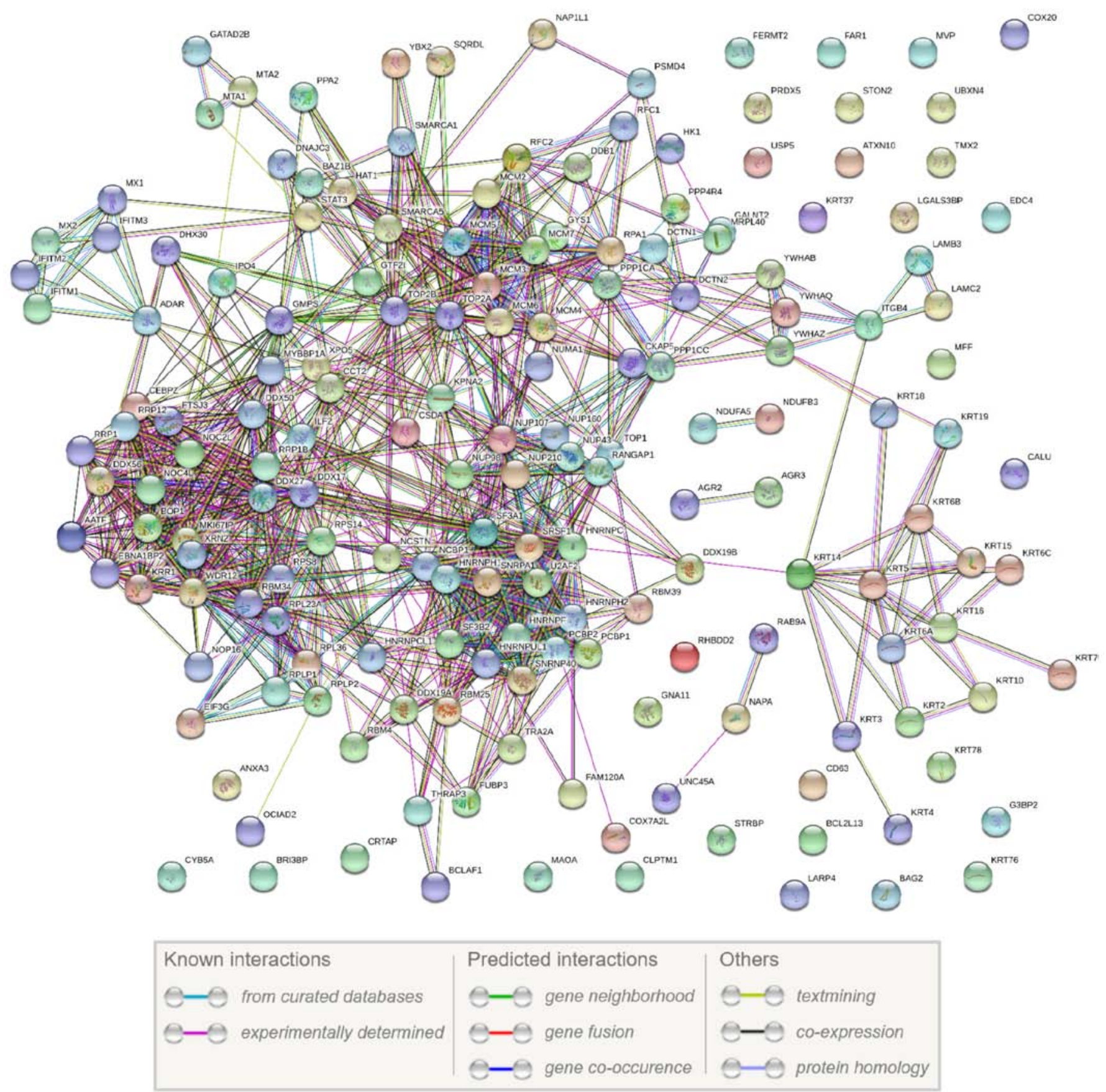

Figure 5. Protein-protein interaction network of the 174 common differentially expressed proteins among the three cancer cell lines and the normal HCK1T cell line. The network illustrates that 142 out of the 174 proteins have at least one functional connection. A total of 31 proteins have no connection to other molecules. The outline of the three-dimensional structure of the proteins is shown within the sphere where it is known or predicted, while there is no particular meaning of the node color itself.

novel insights on a previously inaccessible region of the cell proteome. The findings of this study can be further validated through functional analysis, utilizing techniques such as in vitro gene editing employing the CRISPR/Cas9 system [as reviewed in $(27,28)]$.

Few studies exist on the development of a membrane protein enrichment protocol compatible with proteomics platforms. Previous membrane proteomic studies reported a lower number of membrane protein identifications in comparison with the present study (29-31). Besides the total cell extract and membrane cell extract protocols in the present study, we have also developed in recent studies an enrichment protocol for secreted proteome $(15,16)$. Therefore, the three protocols for total cell extract, membrane cell extract and secretome extract reveal unique identifications and thus offer complementary views of the cellular compartments of the cervical cell lines proteome (14-16).

The current study also contributes to the identification of molecular pathways deregulated in cervical cancer. The most interesting of these pathways are 'HIPPO signaling', 'RAN signaling', 'PI3K/AKT signaling', 'cell cycle: G2/M DNA damage checkpoint regulation' and 'EIF2 signaling', 
Table V. Canonical pathways and involved molecules in the HeLa cell line, as predicted by IPA ${ }^{\mathrm{a}}$.

\begin{tabular}{|c|c|c|c|}
\hline Ingenuity canonical pathways & P-value & Ratio & Molecules \\
\hline \multicolumn{4}{|l|}{$\begin{array}{l}\text { Common predicted pathways } \\
\text { in } \mathrm{SiHa}, \mathrm{HeLa}, \mathrm{C} 33 \mathrm{~A}\end{array}$} \\
\hline Mismatch repair in eukaryotes & $2.69 \times 10^{-5}$ & $4.55 \times 10^{-1}$ & PCNA, RFC2, RFC1, RPA1, RFC5 \\
\hline HIPPO signaling & $7.76 \times 10^{-6}$ & $1.74 \times 10^{-1}$ & $\begin{array}{l}\text { YWHAQ, SMAD2, PPP2R1A, PPP1CC, } \\
\text { YWHAG, YWHAH, YWHAB, SMAD3, } \\
\text { YWHAZ, SCRIB, SKP1, PPP1CA }\end{array}$ \\
\hline $\begin{array}{l}\text { Cell cycle: G2/M DNA damage } \\
\text { checkpoint regulation }\end{array}$ & $1.86 \times 10^{-5}$ & $2.14 \times 10^{-1}$ & $\begin{array}{l}\text { YWHAQ, TOP2B, YWHAG, YWHAH, YWHAB, } \\
\text { PTPMT1, YWHAZ, TOP2A, SKP1 }\end{array}$ \\
\hline EIF2 signaling & $2.45 \times 10^{-5}$ & $1.18 \times 10^{-1}$ & $\begin{array}{l}\text { PABPC1, RPL4, RPS8, RPLP2, RPL30, RPL39, EIF2A, } \\
\text { EIF3G, PPP1CC, RPS27L, EIF2B5, EIF3A, } \\
\text { RPL6, PPP1CA, RPS5, RPS3, RPS14 }\end{array}$ \\
\hline Mitochondrial dysfunction & $6.61 \times 10^{-5}$ & $1.19 \times 10^{-1}$ & 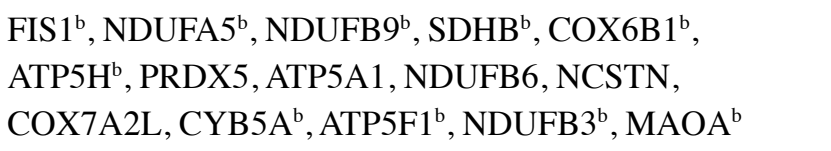 \\
\hline Oxidative phosphorylation & $7.41 \times 10^{-5}$ & $1.51 \times 10^{-1}$ & $\begin{array}{l}\text { NDUFA5, COX6B1, NDUFB9, SDHB, ATP5H, ATP5A1, } \\
\text { NDUFB6, COX7A2L, CYB5A, ATP5F1, NDUFB3 }\end{array}$ \\
\hline $\begin{array}{l}\text { Role of CHK proteins in cell } \\
\text { cycle checkpoint control }\end{array}$ & $4.90 \times 10^{-3}$ & $1.40 \times 10^{-1}$ & PCNA, PPP2R1A, RFC2, RFC1, RPA1, RFC5 \\
\hline RAN signaling & $8.71 \times 10^{-3}$ & $2.50 \times 10^{-1}$ & KPNB1, RANGAP1, KPNA2 \\
\hline PI3K/AKT signaling & $2.95 \times 10^{-2}$ & $8.16 \times 10^{-2}$ & $\begin{array}{l}\text { YWHAQ, MTOR, PPP2R1A, YWHAG, YWHAH, } \\
\text { YWHAB, YWHAZ, PTGS } 2\end{array}$ \\
\hline \multicolumn{4}{|l|}{ Unique predicted pathways in HeLa } \\
\hline Leukotriene biosynthesis & $3.31 \times 10^{-2}$ & $2.50 \times 10^{-1}$ & MGST2 $^{\mathrm{b}}, \mathrm{GGT}^{\mathrm{b}}$ \\
\hline nNOS signaling in skeletal muscle cells & $6.76 \times 10^{-3}$ & $2.73 \times 10^{-1}$ & SNTB2, DMD, DAG1 \\
\hline Glutaryl-CoA degradation & $3.31 \times 10^{-2}$ & $2.50 \times 10^{-1}$ & HADHB, HADH \\
\hline Telomere extension by telomerase & $4.17 \times 10^{-2}$ & $2.22 \times 10^{-1}$ & XRCC6, XRCC5 \\
\hline
\end{tabular}

${ }^{a}$ Molecules participating in the important canonical pathways according to IPA analysis are listed by their gene names; ${ }^{\mathrm{b}}$ Transmembrane proteins. IPA, Ingenuity ${ }^{\circledR}$ Pathway Analysis.

which are common in all cancer cell lines. Specifically, the predicted involvement of the HIPPO signaling pathway in cervical cancer is supported by a recent report on the central role of the HIPPO regulator yes-associated protein 1 in HPV-positive oropharyngeal malignancies (32). The common 174 deregulated proteins in cervical cancer cell lines identified by the present approach exhibit informative associations, as illustrated by the PPI network results (Fig. 5). Among these 174 proteins, $142(82 \%)$ are functionally associated. The overwhelming majority of the interactions in the network $(>90 \%)$ consist of experimentally validated findings.

The comparison of cancer cell lines (C33A, HeLa and $\mathrm{SiHa}$ ) with the normal HCK1T cell line provided a significant number of differentially expressed proteins. Among these, the most notable membrane proteins that were upregulated in all three cancer cell lines, regardless of the presence of HPV, include thioredoxin-related transmembrane protein 2, constitutive coactivator of PPAR- $\gamma$-like protein 1, cleft lip and palate transmembrane protein 1 , nicastrin and cytoskeletonassociated protein 5 . These membrane proteins have not been reported in previous cervical cancer studies; however, published reports support their involvement in other cancer types, as shown in Table III. Nicastrin in particular is considered as a putative therapeutic target in breast cancer $(25,26)$, and further investigation of its potential for cervical cancer therapy is warranted. Thus, the identified membrane proteins reveal novel perspectives for the molecular characterization of cervical cancer. Overall, the successful fractionation of membrane proteins provides a significant pool of potential cervical cancer therapeutic targets for further functional validation and characterization, and eventually for their therapeutic exploitation.

The present study achieved successful isolation of membrane proteins by employing a novel protocol involving differential ultracentrifugation and detergent-based solubilization, generating a significant pool of promising drug targets.

\section{Acknowledgements}

The authors would like to thank Dr Tohru Kiyono (National Cancer Centre Research Institute, Tokyo, Japan) for the generous gift of the normal cervical HCK1T cell line. 
Table VI. Canonical pathways and involved molecules in the C33A cell line, as predicted by IPA ${ }^{\mathrm{a}}$.

\begin{tabular}{|c|c|c|c|}
\hline Ingenuity canonical pathways & P-value & Ratio & Molecules \\
\hline \multicolumn{4}{|l|}{$\begin{array}{l}\text { Common predicted pathways } \\
\text { in } \mathrm{SiHa}, \mathrm{HeLa}, \mathrm{C} 33 \mathrm{~A}\end{array}$} \\
\hline HIPPO signaling & $2.29 \times 10^{-4}$ & $1.59 \times 10^{-1}$ & $\begin{array}{l}\text { YWHAQ, SMAD2, PPP1CC, YWHAE, YWHAB, SMAD3, } \\
\text { CD44, YWHAZ, SCRIB, PPP2R5E, PPP1CA }\end{array}$ \\
\hline EIF2 signaling & $6.31 \times 10^{-12}$ & $2.01 \times 10^{-1}$ & $\begin{array}{l}\text { RPS18, RPLP2, RPL39, EIF2A, RPS11, RPS7, RPL27A, } \\
\text { PPP1CC, EIF3B, EIF3A, GSK3B, RPS2, RPS5, RPS3, PPP1CA, } \\
\text { RPL18, PABPC1, RPS19, RPL4, RPL3, RPS8, RPL30, } \\
\text { RPS10, RPL12, EIF3G, RPL6, RPSA, RPS14, RPLP0 }\end{array}$ \\
\hline Cell cycle: G2/M DNA damage & $1.20 \times 10^{-5}$ & $2.38 \times 10^{-1}$ & $\begin{array}{l}\text { YWHAQ, CDKN2A, TOP2B, YWHAE, YWHAB, } \\
\text { YWHAZ, TRIP12, TOP2A, PLK1, CCNB1 }\end{array}$ \\
\hline \multicolumn{4}{|l|}{ checkpoint regulation } \\
\hline Mismatch repair in eukaryotes & $2.69 \times 10^{-5}$ & $4.55 \times 10^{-1}$ & PCNA, RFC2, RFC1, RPA1, RFC5 \\
\hline Mitochondrial dysfunction & $6.61 \times 10^{-5}$ & $1.19 \times 10^{-1}$ & 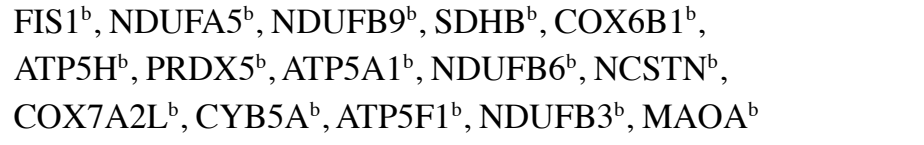 \\
\hline Oxidative phosphorylation & $7.41 \times 10^{-5}$ & $1.51 \times 10^{-1}$ & $\begin{array}{l}\text { NDUFA5, COX6B1, NDUFB9, SDHB, ATP5H, ATP5A1, } \\
\text { NDUFB6, COX7A2L, CYB5A, ATP5F1, NDUFB3 }\end{array}$ \\
\hline $\begin{array}{l}\text { Role of CHK proteins in cell } \\
\text { cycle checkpoint control }\end{array}$ & $4.90 \times 10^{-3}$ & $1.40 \times 10^{-1}$ & PCNA, PPP2R1A, RFC2, RFC1, RPA1, RFC5 \\
\hline PI3K/AKT signaling & $1.23 \times 10^{-2}$ & $1.02 \times 10^{-1}$ & $\begin{array}{l}\text { YWHAQ, ITGB1, MTOR, ITGA3, YWHAE, YWHAB, } \\
\text { YWHAZ, GSK3B, PPP2R5E, GYS2 }\end{array}$ \\
\hline RAN signaling & $1.45 \times 10^{-2}$ & $2.50 \times 10^{-1}$ & KPNB1, RANGAP1, KPNA2 \\
\hline \multicolumn{4}{|l|}{ Unique predicted pathways in $\mathrm{C} 33 \mathrm{~A}$} \\
\hline $\begin{array}{l}\text { Sertoli cell-Sertoli cell } \\
\text { junction signaling }\end{array}$ & $7.94 \times 10^{-3}$ & $9.56 \times 10^{-2}$ & 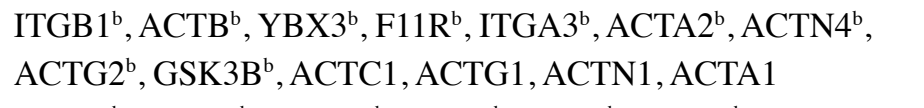 \\
\hline $\begin{array}{l}\text { Caveolar-mediated } \\
\text { endocytosis signaling }\end{array}$ & $1.35 \times 10^{-5}$ & $1.97 \times 10^{-1}$ & $\begin{array}{l}\text { ITGB }^{\mathrm{b}}, \mathrm{ITGA}^{\mathrm{b}}, \mathrm{ACTA}^{\mathrm{b}}, \mathrm{ACTB}^{\mathrm{b}}, \mathrm{CAV} 1^{\mathrm{b}}, \mathrm{ITGB}^{\mathrm{b}}{ }^{\mathrm{T}} \\
\mathrm{ACTG}^{\mathrm{b}}, \mathrm{PTRF}^{\mathrm{b}}, \mathrm{ACTC}^{\mathrm{b}}, \mathrm{ACTG}, \mathrm{ACTA} 1, \mathrm{EGFR}\end{array}$ \\
\hline $\begin{array}{l}\text { Remodeling of epithelial } \\
\text { adherens junctions }\end{array}$ & $1.82 \times 10^{-5}$ & $2.08 \times 10^{-1}$ & $\begin{array}{l}\text { ARPC1B, ACTA2, ACTB, ACTG2, ACTN4, IQGAP1, } \\
\text { ACTC1, ACTG1, ACTA1, ACTN1, ARPC4 }\end{array}$ \\
\hline $\begin{array}{l}\text { Agrin interactions at } \\
\text { neuromuscular junction }\end{array}$ & $7.24 \times 10^{-5}$ & $1.96 \times 10^{-1}$ & $\begin{array}{l}\text { ITGB }^{\mathrm{b}}, \mathrm{ITGA}^{\mathrm{b}}, \mathrm{PKLR}^{\mathrm{b}}, \mathrm{ACTA}^{\mathrm{b}}, \mathrm{ACTB}^{\mathrm{b}}, \mathrm{ACTG}^{\mathrm{b}}{ }^{\mathrm{b}}, \\
\text { ACTC }^{\mathrm{b}}, \mathrm{ACTG}^{\mathrm{b}}, \mathrm{ACTA}^{\mathrm{b}}, \mathrm{EGFR}^{\mathrm{b}}\end{array}$ \\
\hline RhoGDI signaling & $7.94 \times 10^{-5}$ & $1.34 \times 10^{-1}$ & 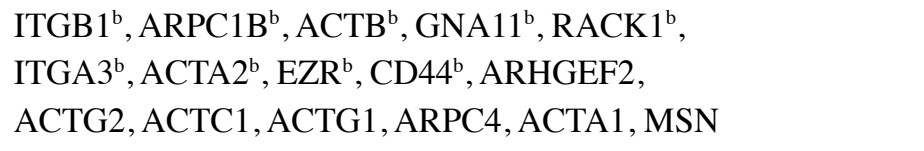 \\
\hline $\begin{array}{l}\text { NRF2-mediated oxidative } \\
\text { stress response }\end{array}$ & $2.40 \times 10^{-4}$ & $1.18 \times 10^{-1}$ & $\begin{array}{l}\text { DNAJB12 }{ }^{\mathrm{b}}, \mathrm{PPIB}^{\mathrm{b}}, \mathrm{ACTB}^{\mathrm{b}}, \mathrm{DNAJC}^{\mathrm{b}}, \mathrm{CUL}^{\mathrm{b}}, \mathrm{ACTA}^{\mathrm{b}}, \\
\text { SCARB }^{\mathrm{b}}, \mathrm{MGST}^{\mathrm{b}}, \mathrm{CCT} 7, \mathrm{GSK} 3 \mathrm{~B}, \\
\text { ACTG} 2, \text { DNAJB6, ACTC1, HACD3, ACTG1, ACTA1, CBR1 }\end{array}$ \\
\hline $\begin{array}{l}\text { Regulation of actin-based } \\
\text { motility by Rho }\end{array}$ & $4.47 \times 10^{-4}$ & $1.59 \times 10^{-1}$ & $\begin{array}{l}\text { ITGB }^{\mathrm{b}}, \mathrm{ITGA}^{\mathrm{b}}{ }^{\mathrm{A}}, \mathrm{ARP} 1 \mathrm{~B}^{\mathrm{b}}, \mathrm{ACTA}^{\mathrm{b}}, \mathrm{ACTB}^{\mathrm{b}}, \mathrm{ACTG}^{\mathrm{b}} \text {, } \\
\mathrm{GSN}^{\mathrm{b}}, \mathrm{ACTC}^{\mathrm{b}}, \mathrm{ACTA}^{\mathrm{b}}, \mathrm{ARPC}^{\mathrm{b}}\end{array}$ \\
\hline ILK signaling & $8.32 \times 10^{-4}$ & $1.10 \times 10^{-1}$ & 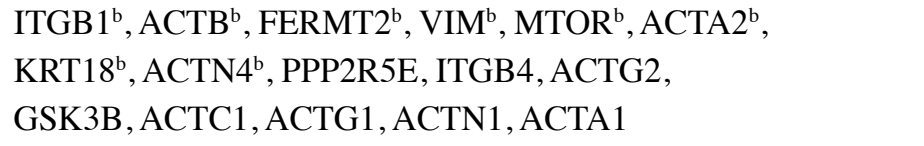 \\
\hline $\begin{array}{l}\text { Mechanisms of viral exit } \\
\text { from host cells }\end{array}$ & $8.51 \times 10^{-4}$ & $2.31 \times 10^{-1}$ & ACTA2, ACTB, ACTG2, ACTC1, ACTG1, ACTA1 \\
\hline Glycolysis I & $1.23 \times 10^{-3}$ & $2.63 \times 10^{-1}$ & PKLR, ENO3, ENO2, GAPDH, PFKP \\
\hline Integrin signaling & $1.51 \times 10^{-3}$ & $1.01 \times 10^{-1}$ & $\begin{array}{l}\text { ITGB }^{\mathrm{b}}, \mathrm{ARPC}^{\mathrm{AR}}{ }^{\mathrm{b}}, \mathrm{ACTB}^{\mathrm{b}}, \mathrm{GSN}^{\mathrm{b}}, \mathrm{ITGA}^{\mathrm{b}}, \mathrm{ACTA}^{\mathrm{b}}, \\
\mathrm{CAV}^{\mathrm{b}}, \mathrm{CAPN}^{\mathrm{b}}, \mathrm{ACTN}^{\mathrm{b}}, \mathrm{ASK}^{\mathrm{b}} \mathrm{B}^{\mathrm{b}}, \mathrm{ITGB}^{\mathrm{b}}, \mathrm{ACTG}^{\mathrm{b}}, \\
\text { ACTC }^{\mathrm{b}}, \mathrm{ACTG}^{\mathrm{b}}, \mathrm{ARPC}^{\mathrm{b}}, \mathrm{ACTN}^{\mathrm{A}}, \mathrm{ACTA}^{\mathrm{b}}\end{array}$ \\
\hline Paxillin signaling & $2.04 \times 10^{-3}$ & $1.24 \times 10^{-1}$ & $\begin{array}{l}\text { ITGB }^{\text {b }}{ }^{\text {ITGA }} 3^{\mathrm{b}}, \mathrm{ACTA}^{\mathrm{b}}, \mathrm{ACTB}^{\mathrm{b}}, \mathrm{ITGB}^{\mathrm{b}}, \mathrm{ACTG}^{\mathrm{b}}{ }^{\mathrm{A}}, \\
\text { ACTN }^{\mathrm{b}}, \mathrm{ACTC}^{\mathrm{b}}, \mathrm{ACTG}^{\mathrm{b}}, \mathrm{ACTA}^{\mathrm{b}}, \mathrm{ACTN}^{\mathrm{b}}\end{array}$ \\
\hline
\end{tabular}


Table VI. Continued.

\begin{tabular}{|c|c|c|c|}
\hline Ingenuity canonical pathways & P-value & Ratio & Molecules \\
\hline FAK signaling & $3.24 \times 10^{-3}$ & $1.23 \times 10^{-1}$ & 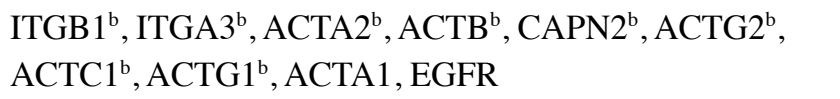 \\
\hline Actin cytoskeleton signaling & $3.39 \times 10^{-3}$ & $9.58 \times 10^{-2}$ & 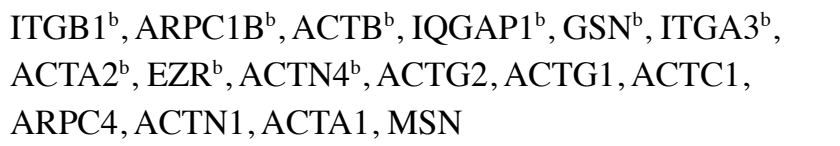 \\
\hline Death receptor signaling & $4.27 \times 10^{-3}$ & $1.27 \times 10^{-1}$ & $\begin{array}{l}\text { ACIN1, ACTA2, ACTB, LMNA, ACTG2, ACTC1, } \\
\text { ACTG1, ACTA1, HSPB1 }\end{array}$ \\
\hline $\begin{array}{l}\text { Regulation of cellular mechanics } \\
\text { by Calpain protease }\end{array}$ & $4.68 \times 10^{-3}$ & $1.49 \times 10^{-1}$ & 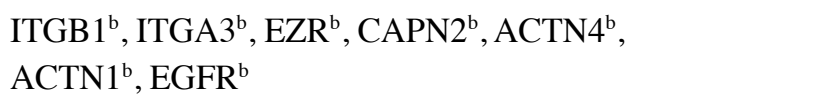 \\
\hline Leukocyte extravasation signaling & $5.13 \times 10^{-3}$ & $9.43 \times 10^{-2}$ & 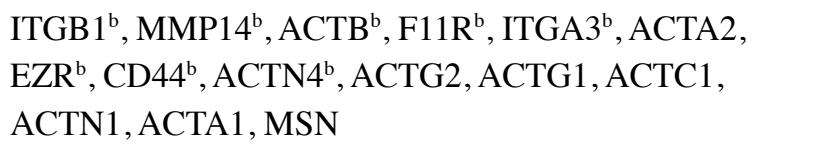 \\
\hline $\begin{array}{l}\text { 2-Ketoglutarate dehydrogenase } \\
\text { complex }\end{array}$ & $5.89 \times 10^{-3}$ & $6.67 \times 10^{-1}$ & DLST, DLD \\
\hline $\begin{array}{l}\text { Fc } \gamma \text { receptor-mediated phagocytosis } \\
\text { in macrophages and monocytes }\end{array}$ & $6.17 \times 10^{-3}$ & $1.20 \times 10^{-1}$ & $\begin{array}{l}\text { ARPC1B, ACTA2, EZR, ACTB, ACTG2, ACTC1, } \\
\text { ACTG1, ACTA1, ARPC4 }\end{array}$ \\
\hline $\begin{array}{l}\text { Epithelial adherens junction } \\
\text { signaling }\end{array}$ & $7.08 \times 10^{-3}$ & $1.01 \times 10^{-1}$ & $\begin{array}{l}\text { ARPC1B, ACTA2, ACTB, ACTG2, ACTN4, IQGAP1, } \\
\text { ACTC1, ACTG1, ACTA1, ACTN1, ARPC4, EGFR }\end{array}$ \\
\hline TCA cycle II eukaryotic & $7.41 \times 10^{-3}$ & $2.22 \times 10^{-1}$ & CS, DLST, DLD, FH \\
\hline VEGF signaling & $1.26 \times 10^{-2}$ & $1.07 \times 10^{-1}$ & $\begin{array}{l}\text { YWHAE, ACTA2, ACTB, ACTG2, ACTN4, ACTC1, } \\
\text { ACTG1, ACTA1, ACTN1 }\end{array}$ \\
\hline Tec kinase signaling & $1.38 \times 10^{-2}$ & $9.23 \times 10^{-2}$ & 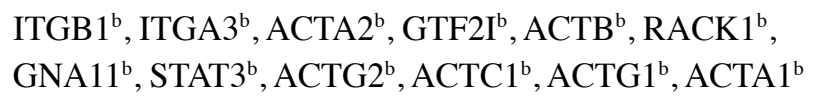 \\
\hline$\gamma$-Linolenate biosynthesis II animals & $1.45 \times 10^{-2}$ & $2.50 \times 10^{-1}$ & $\mathrm{CYB}^{\mathrm{b}} \mathrm{A}^{\mathrm{b}}, \mathrm{ACSL1}^{\mathrm{b}}, \mathrm{FADS}^{\mathrm{b}}$ \\
\hline MSP-RON signaling pathway & $1.62 \times 10^{-2}$ & $1.30 \times 10^{-1}$ & ACTA2, ACTB, ACTG2, ACTC1, ACTG1, ACTA1 \\
\hline $\begin{array}{l}\text { Germ cell-Sertoli cell } \\
\text { junction signaling }\end{array}$ & $1.82 \times 10^{-2}$ & $8.89 \times 10^{-2}$ & 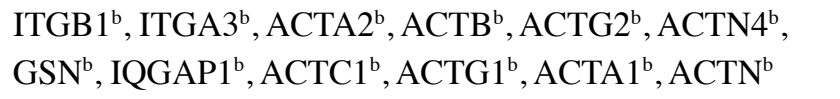 \\
\hline $\begin{array}{l}\text { Clathrin-mediated } \\
\text { endocytosis signaling }\end{array}$ & $3.55 \times 10^{-2}$ & $8.05 \times 10^{-2}$ & 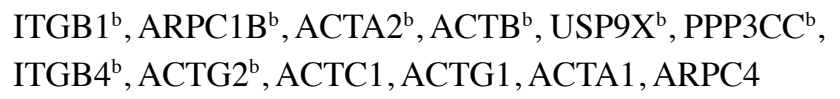 \\
\hline $\begin{array}{l}\text { Agranulocyte adhesion } \\
\text { and diapedesis }\end{array}$ & $3.63 \times 10^{-2}$ & $8.27 \times 10^{-2}$ & 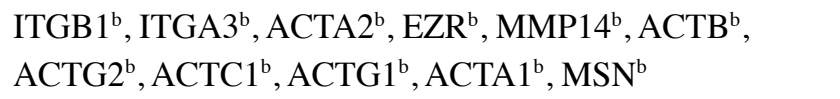 \\
\hline RAR activation & $3.72 \times 10^{-2}$ & $8.00 \times 10^{-2}$ & $\begin{array}{l}\text { NR2F1, SMAD2, SMAD9, SMAD3, ACTB, SMARCB1, } \\
\text { NR2F2, SMARCD2, ARID2, SNW1, SMARCC1, PRMT1 }\end{array}$ \\
\hline $\begin{array}{l}\text { Glycoaminoglycan-protein linkage } \\
\text { region biosynthesis }\end{array}$ & $4.47 \times 10^{-2}$ & $1.18 \times 10^{-3}$ & GXYLT1 ${ }^{\mathrm{b}}$ \\
\hline $\begin{array}{l}\text { Phosphatidylethanolamine } \\
\text { biosynthesis III }\end{array}$ & $4.47 \times 10^{-2}$ & $1.02 \times 10^{-2}$ & PTDSS $2^{b}$ \\
\hline $\begin{array}{l}\text { Branched-chain } \alpha \text {-keto acid } \\
\text { dehydrogenase complex }\end{array}$ & $4.47 \times 10^{-2}$ & $1.07 \times 10^{-1}$ & DLD \\
\hline $\begin{array}{l}\text { Assembly of RNA polymerase III } \\
\text { complex }\end{array}$ & $4.68 \times 10^{-2}$ & $2.50 \times 10^{-1}$ & GTF3C1, SF3A1 \\
\hline
\end{tabular}

${ }^{a}$ Molecules participating in the important canonical pathways according to IPA analysis are listed by their gene names; ${ }^{b}$ Transmembrane proteins. IPA, Ingenuity ${ }^{\circledR}$ Pathway Analysis.

\section{Funding}

This study was funded by the European Union's European Social Fund and Greek National Funds through the Program THALIS, under the Operational Program Education and Lifelong Learning of the National Strategic Reference Framework (grant no. 70-3-11830), and by the Oncology Program of the Central Council of Health of the Ministry of Health (grant no. 70-3-9209). 


\section{Availability of data and materials}

The datasets used and/or analyzed during the current study are available from the corresponding author on reasonable request.

\section{Authors' contributions}

KIP, JZ and NPA participated in the acquisition of funding, and study design and supervision. KIP interpreted the results and drafted the manuscript. PC, AX and GM performed the experiments and statistical analysis, and contributed to the writing of the manuscript. GK performed the cell culture and Ingenuity ${ }^{\circledR}$ Pathway Analysis. VL created the protein-protein interactions network. MM performed the mass spectrometry analysis. All authors read and approved the final manuscript.

\section{Ethics approval and consent to participate}

Not applicable.

\section{Consent for publication}

Not applicable.

\section{Competing interests}

The authors declare that they have no competing interests.

\section{References}

1. Feichtinger M and Rodriguez-Wallberg KA: Fertility preservation in women with cervical, endometrial or ovarian cancers. Gynecol Oncol Res Pract 3: 8, 2016.

2. Li Y and Xu C: Human papillomavirus-related cancers. Adv Exp Med Biol 1018: 23-34, 2017.

3. Serrano B, Brotons M, Bosch FX and Bruni L: Epidemiology and burden of HPV-related disease. Best Pract Res Clin Obstet Gynaecol 47: 14-26, 2018.

4. Pappa KI, Kontostathi G, Lygirou V, Zoidakis J and Anagnou NP: Novel structural approaches concerning HPV proteins: Insight into targeted therapies for cervical cancer (Review). Oncol Rep 39: 1547-1554, 2018.

5. Willows K, Lennox $G$ and Covens A: Fertility-sparing management in cervical cancer: Balancing oncologic outcomes with reproductive success. Gynecol Oncol Res Pract 3: 9, 2016.

6. Parkin DM: Cancer in developing countries. Cancer Surv 19-20. 519-561, 1994.

7. Bentivegna E, Maulard A, Pautier P, Chargari C, Gouy S and Morice P: Fertility results and pregnancy outcomes after conservative treatment of cervical cancer: A systematic review of the literature. Fertil Steril 106: 1195-1211 e1195, 2016.

8. Lawrenz B, Mahajan N and Fatemi HM: The effects of cancer therapy on women's fertility: What do we know now? Future Oncol 12: 1721-1729, 2016.

9. Barra F, Lorusso D, Leone Roberti Maggiore U, Ditto A, Bogani G, Raspagliesi $F$ and Ferrero S: Investigational drugs for the treatment of cervical cancer. Expert Opin Investig Drugs 26: 389-402, 2017.

10. Hampson L, Martin-Hirsch P and Hampson IN: An overview of early investigational drugs for the treatment of human papilloma virus infection and associated dysplasia. Expert Opin Investig Drugs 24: 1529-1537, 2015.

11. Campbell MT, Siefker-Radtke AO and Gao J: The state of immune checkpoint inhibition in urothelial carcinoma: Current evidence and future areas of exploration. Cancer J 22: 96-100, 2016.

12. Mermelekas G and Zoidakis J: Mass spectrometry-based membrane proteomics in cancer biomarker discovery. Expert Rev Mol Diagn 14: 549-563, 2014.

13. Tomonaga $\mathrm{T}$ and Kume $\mathrm{H}$ : Biomarker discovery of colorectal cancer using membrane proteins extracted from cancer tissues. Rinsho Byori 63: 322-327, 2015 (In Japanese).
14. Pappa KI, Lygirou V, Kontostathi G, Zoidakis J, Makridakis M, Vougas K, Daskalakis G, Polyzos A and Anagnou NP: Proteomic analysis of normal and cancer cervical cell lines reveals deregulation of cytoskeleton-associated proteins. Cancer Genomics Proteomics 14: 253-266, 2017.

15. Kontostathi G, Zoidakis J, Makridakis M, Lygirou V, Mermelekas G, Papadopoulos T, Vougas K, Vlamis-Gardikas A, Drakakis P, Loutradis D, et al: Cervical cancer cell line secretome highlights the roles of transforming growth factor-beta-induced protein ig-h3, peroxiredoxin-2, and NRF2 on cervical carcinogenesis. Biomed Res Int 2017: 4180703, 2017.

16. Pappa KI, Kontostathi G, Makridakis M, Lygirou V, Zoidakis J, Daskalakis G and Anagnou NP: High resolution proteomic analysis of the cervical cancer cell lines secretome documents deregulation of multiple proteases. Cancer Genomics Proteomics 14: 507-521, 2017.

17. Makridakis M, Gagos S, Petrolekas A, Roubelakis MG, Bitsika V, Stravodimos K, Pavlakis K, Anagnou NP, Coleman J and Vlahou A: Chromosomal and proteome analysis of a new T24-based cell line model for aggressive bladder cancer. Proteomics 9: 287-298, 2009.

18. Narisawa-Saito M, Handa K, Yugawa T, Ohno S, Fujita M and Kiyono T: HPV16 E6-mediated stabilization of ErbB2 in neoplastic transformation of human cervical keratinocytes. Oncogene 26: 2988-2996, 2007.

19. Eng JK, Fischer B, Grossmann J and Maccoss MJ: A fast SEQUEST cross correlation algorithm. J Proteome Res 7: 4598-4602, 2008.

20. Apostolou P, Toloudi M and Papasotiriou I: Identification of genes involved in breast cancer and breast cancer stem cells. Breast Cancer (Dove Med Press) 7: 183-191, 2015.

21. Holden S and Raymond FL: The human gene CXorf17 encodes a member of a novel family of putative transmembrane proteins: cDNA cloning and characterization of CXorf17 and its mouse ortholog orf34. Gene 318: 149-161, 2003.

22. Bartolomé RA, García-Palmero I, Torres S, López-Lucendo M, Balyasnikova IV and Casal JI: IL13 Receptor $\alpha 2$ signaling requires a scaffold protein, FAM120A, to activate the FAK and PI3K pathways in colon cancer metastasis. Cancer Res 75: 2434-2444, 2015.

23. Zang Y,Nie W,Fang Z and Li B: Cleft lip and palate transmembrane protein $1 \mathrm{rs} 31489$ polymorphism is associated with lung cancer risk: A meta-analysis. Tumour Biol 35: 5583-5588, 2014.

24. Schneider MA, Christopoulos P, Muley T, Warth A, Klingmueller U, Thomas M, Herth FJ, Dienemann H, Mueller NS, Theis F, et al: AURKA, DLGAP5, TPX2, KIF11 and CKAP5: Five specific mitosis-associated genes correlate with poor prognosis for non-small cell lung cancer patients. Int J Oncol 50: 365-372, 2017.

25. Sarajlić A, Filipović A, Janjić V, Coombes RC and Pržulj N: The role of genes co-amplified with nicastrin in breast invasive carcinoma. Breast Cancer Res Treat 143: 393-401, 2014.

26. Lombardo Y,Filipović A, Molyneux G, Periyasamy M, Giamas G, Hu Y, Trivedi PS, Wang J, Yagüe E, Michel L, et al: Nicastrin regulates breast cancer stem cell properties and tumor growth in vitro and in vivo. Proc Natl Acad Sci USA 109: 16558-16563, 2012.

27. Sander JD and Joung JK: CRISPR-Cas systems for editing, regulating and targeting genomes. Nat Biotechnol 32: 347-355, 2014.

28. Doudna JA and Charpentier E: Genome editing. The new frontier of genome engineering with CRISPR-Cas9. Science 346: 1258096, 2014

29. Hua Y, Jia X, Sun M, Zheng L, Yin L, Zhang L and Cai Z: Plasma membrane proteomic analysis of human osteosarcoma and osteoblastic cells: Revealing NDRG1 as a marker for osteosarcoma. Tumour Biol 32: 1013-1021, 2011.

30. Qu Z, Gao F, Li L, Zhang Y, Jiang Y, Yu L, Zhou Y, Zheng H, Tong W, Li G, et al: Label-free quantitative proteomic analysis of differentially expressed membrane proteins of pulmonary alveolar macrophages infected with highly pathogenic porcine reproductive and respiratory syndrome virus and its attenuated strain. Proteomics 17: 1700101, 2017.

31. Zhang Z, Zhang L, Hua Y, Jia X, Li J, Hu S, Peng X, Yang P, Sun M, Ma F, et al: Comparative proteomic analysis of plasma membrane proteins between human osteosarcoma and normal osteoblastic cell lines. BMC Cancer 10: 206, 2010.

32. Alzahrani F, Clattenburg L, Muruganandan S, Bullock M, MacIsaac K, Wigerius M, Williams BA, Graham ME, Rigby MH, Trites JR, et al: The hippo component YAP localizes in the nucleus of human papilloma virus positive oropharyngeal squamous cell carcinoma. J Otolaryngol Head Neck Surg 46: 15, 2017. 